\title{
EFFECT OF BUDGETARY PARTICIPATION ON BUDGETARY SLACK WITH MODERATION VARIABLES ARE ORGANIZATIONAL CULTURE, ENVIRONMENTAL UNCERTAINTY AND INFORMATIONASYMMETRY
}

\author{
Reza Muhammad Rizqi ${ }^{1}$, Rr. Titik Herwanti ${ }^{1}$ and Budi Santoso ${ }^{1}$ \\ ${ }^{1}$ Master of Accounting Faculty of Economics, University of Mataram \\ *)E-mail: rezamr24@gmail.com
}

\begin{abstract}
The problems of this research is occurred in previous studies on the influence of budgetary participation on budgetary slack and high budgetary slack happened at Hospital of Sumbawa Besar become the motivation in this research. Data collection was done through the distribution of questionnaires to the responden,from 48 questionnaires, only 45 questionnaires could be used. This study used a model based on the SEM variant of SmartPLS. The research instrument has passed the validity and reliability test. The results showed that budgetary participation have effect on budgetary slack. This study may identification the interaction between budgetary participation and organizational culture has a positive and significant effect on budgetary slack, environmental uncertainty has a negative and significant effect, and information asymmetry has a negative and significant effect between budgetary participation and budgetary slack. The implications of this study are expected to be useful for the hospital and the government so that it can be a guide in preparing and setting a more effective and efficient budget, so that the goals of the organization can be easily achieved.
\end{abstract}

Keywords: Budgetary Participation, Organizational Culture, Environmental Uncertainty, Information Asymmetry, Budgetary Slack.

\section{Introduction}

In the current era of globalization, companies are required to make a change from every field both in terms of vision, the mission and company perspective, this is to be done for promote the goals of the company. Brigham and Daves (2010) believes that the company can increase the wealth of the members of the shareholders of the company, which is the most important targets to be achieved by each company, of course it is not out of control management and budgeting are well within the company. Management control system is a very important part in managing the company. Basically, management control is a process carried out by the manager to influence subordinates to want to implement corporate strategy. In the system management control, budget plays an important role as a management tool to control the operation of the company to an established strategy can be used to achieve its goals. Speaking on the budget, cannot be separated from the finance company used by profit-oriented and non-profit. For an enterprise, budgeting is a medium that is used to help carry out the activities to be more effective, for example for a planning tool and a means of controlling others.

In a traditional budgeting models, made with system, topdown where the plan and the budget amount assigned by superiors to subordinates just do what you have prepared (Govindarajan, 2005). Implementation of this system will create a superior result in less know the potential and constraints faced by subordinates to provide a target which is very high compared with the low ability of subordinates. Starting from this condition, some good company in the private sector or the public began to implement a budgeting system that can fix above problems, namely budgetary participation, when subordinates involved in the preparation of the budget concerning the sub-parts in order to reach an agreement between superiors and subordinates of the budget (Anthony, 2005) Participation budget assessed as having consequences on the attitudes and behavior of members of the organization (Murray, 1990 in Sumarno, 2005). Utomo (2006) points when the participation of the budget is not implemented properly can encourage subordinates perform budgetary slack. Research on budgetary slack have a significant problem in many companies, which until now still attract the attention of researchers. economic theory and behavior, such as the principal / agent, goal setting, or the theory of organizational justice can be used to study this budgetary slack, but generate conflicting predictions due to several variables. Many studies conducted to analyze the factors that can lead to the tendency of creating slackThe. One factor that is widely studied and considered to have a significant effect on the emergence of slackis the participation of the budget.

Budgetary slack phenomenon common in Sumbawa District Hospital, where one example of budgetary slack that occurred at the General Hospital (Hospital) Sumbawa Besar is revenue Public Services. Revenues from public services are the responsibility of the health services unit and the services contained on Sumbawa Besar Hospital. Data budgeting for Fiscal Year (FY) 
2016 budget realization of Sumbawa Besar hospital amounted Rp.55.666.040.652,00 of the target of Rp.75.866.296.445,00. Then the target for FY 2017 amounted to Rp.94.319.834.995,00 (RBA Hospital Sumbawa Year 2017). In this case we can see that the targets set in the Business Plan Budget Hospital Sumbawa Besar 2016 was higher than that realized but part of budgeting Hospital Sumbawa Besar has set a higher target again for next year irrespective of the target has not been achieved in previous year (2016). It describes their dysfunctional behavior (sejangan budget) that occur in Sumbawa Besar Hospital, where the difference in the difference in budget of Rp20.200.255.793,00. By looking at the magnitude of the budget, it can be concluded budgeting established by the Hospital Sumbawa Besar ineffective, so that if this trend continues the possibility of irregularities in the use of the budget is likely to be greater.

Research on budgetary slack has been done to explain that the subordinate participation in budget making will result in budgetary slack. Research Kahar (2016) In particular, this study provides empirical evidence that participatory budgeting factors affecting budgetary slack suggesting that high levels of participation give managers the opportunity to bring up slack by subordinates. However, some studies do not support these findings, as examples of Sundari, et al (2016) states that there is no significant effect between budgetary participation and budgetary slack, thus causing a lot of conflict of opinions and facts that make budgetary slack becomes more complex to continue to be discussed.

Factors affecting budgetary slack also continues to grow with the inclusion of other variables that are considered influential one such as environmental uncertainty. In research Asak (2016) states that the effect of ketiakpastian environment able to moderate (weaken) the effect of budgetary participation on budgetary slack, this is reinforced by research conducted by Kartika (2010), Amrul and Nasir (2002), and Yuwono (1999). Research Anggraeni 2008 examined the budgetary participation, information asymmetry, and budget emphasis as independent variables, and slackbudgetsas the dependent variable, the results of his research is that the budgetary participation and budget emphasis has an influence on slackbudget, while the asymmetric information has no effect on budgetary slack. Another study was also carried out by (Anissarahma, 2008) and obtained the results of studies showing that the participation of the budget, asymmetric information, budget emphasis and organizational commitment affect the slackbudget.

Some previous studies also indicate problems that are unclear and inconsistent about the relationship between budget participation with budgetary slack, previous studies have examined the effect of budget participation on budgetary slack, among others Falikhatun (2007), Sudarba (2010), Andriyani and Hidayati (2010), Nasution (2011), stated that the participation of the budget may lead to budgetary slack. Unlike Utomo (2006), Supanto (2010), Martjin and Wiersma (2011) that the participatory budget can lower the occurrence of budgetary slack. The inconsistency of the results were expected because there are other variables that affect the relationship between budget participation with the possibility of budgetary slack. Based on the results of previous studies, which generally have inconsistent results, and still raises questions for other researchers, so this research is motivated to try to reexamine Effect Against budgetParticipation on budgetary slack with moderating variables Organizational Culture, Environmental Uncertainty and Asymmetry Information.

This study aims to prove the effect of budget participation on budgetary slack with moderating variable of organizational culture and environmental uncertainty. This study is expected to provide a positive contribution in the field of management accounting, particularly in terms of budget management to improve the effectiveness and efficiency of use of the budget. In addition this study expected to be useful for employees and employees in Sumbawa BesarHospital, so it can be input and consideration in determining the budget to fit the needs of the hospital.

\section{Agency Theory}

Agency theory explained that the agency relationship arises when one or more persons (theprincipal)employs another person(the agent)to provide a service and then delegate decision-making authority to agent (Jensen and Meckling, 1976). While Hendriksen and Michael (2000) states the agent closes a contract to perform certain tasks for the principal and the principal conclude contracts to reward agents. Analogues such as between business owners and management companies. Conflicts of interest between agents and principals will continue to increase, because the principal cannot monitor agent activity every day. Participation budget can be explained by the theory of agency, where agents have a lot more important information regarding the capacity of self, work environment and the organization as a whole. Jensen and Meckling (1976) suggests the existence of problems in the company, among others: 1) moral hazard are problems that arise because agents do not carry out the things that have been agreed under the contract of employment; and

2) adverse selection is the principal does not know that the decision taken by the agent is a decision that according to the information received by the principal or negligence in duty. Conflicts that arise is the description of the dividend policy, financing, and investment that are used by investors to set up the manager and transfer profits from the wealth of creditors (Jensen and Meckling, 1976).

\section{Contigency Theory}

Contigency theory can be used to analyze the design and management accounting systems to provide the information can be used by companies for a variety of purposes (Otley, 1980) and to face competition (Mia and Clarke, 1999). According to Otley (1980) The control systems are influenced by the context in which they operate and need to be adapted to the needs and circumstances of the organization. The premise of the Contingency Theory there is no universal control system which is always appropriate to be applied to the entire organization in every state. As for the 
contingency factor used in this research is the organizational culture, environmental uncertainty and information asymmetry. These factors will play a role as a moderating the relationship between budget participation on budgetary slack. Contingency theory is able to push a situation that allows for the analysis of the situation prior to take action and eliminate the usual behavior is based on assumptions about behavior. In addition, the contingency theory if applied properly can be utilized for all of the latest knowledge about the organization, because the right action depends on situational variables (Davis and Newstrom, 1985).

\section{Factors Affecting the Budgetary Slack}

Research on the factors that influence the emergence of slackbudgets have been carried out by economists, are as follows:

\section{1) Budgetary Participation}

One factor that is widely studied and considered to have a significant effect on the emergence of slackis the participation of the budget. A high participative budget will increase budgetary slack (Sudarba, 2010). Research Kahar (2016) In particular, this study provides empirical evidence that participatory budgeting factors affecting budgetary slack mediated by intervening variables job satisfaction factors. The results showed a significant negative effect on the

participatory budgeting budgetary slack. Siegel and Marconi (1989) states that participation in the budgeting process can provide benefits include:

a) People who are involved in the budgeting process is not only a task involved but also ego Involved in carrying out their work.

b) Someone would increase the sense of togetherness in the group because it can improve collaboration between group members in their goal setting, but it can relieve pressure from their budgets.

c) Reduce the sense of inequality in allocating available resources among the divisions that exist within the organization.

\section{2) Organizational Culture}

Every organization must have a different definition of organizational culture. According to Robbins (2008), organizational culture is a common value system within an organization that determines the degree of how employees carry out activities to achieve organizational goals. Organizational culture is also defined as one that is guided by the values of human resources in the face of external issues and attempt to understand the values that exist and understand how they should act and behave (Susanto, 1997).

All human resources must be able to understand the true culture of the organization, because this understanding is associated with every step or activity carried out, both for strategic planning and tactical and planning impleentasi activities, where each of these activities must be based on the culture of the organization.

According to Holmes and Marsden (1996) in Sardjito and Muthaher (2007), organizational culture affects the behavior, how to work and motivation of superiors and subordinates to achieve organizational performance. Cultural organizations in Robbins and Judge (2008) measured seven key characteristics that constitute the essence of the culture of an organization, namely:

a) Innovation and the courage to take a risk is the level of an employee who is motivated to be innovative and take risks;

b) Attention to detail matters is the level of an employee who is expected to run precision, analysis and attention to the detail;

c) The orientation of the results is how high the level of management to better focus on the outcome rather than the techniques and processes used to achieve those results;

d) The orientation of people is how highlevel management decisions consider the effect of these results on the person in the organization;

e) The orientation team is how high the level of activities in the organization of work in teams rather than individuals;

f) Aggressiveness is the level of someone being aggressive and competitive than relaxing in the work;

g) Stability is how high the level of activities of the organization stressed the effort to maintain the status quo in comparison with growth.

Results of research conducted Usman (2012) showed the importance of values in the organizational culture affect behavior and attitudes of individuals. The results showed that organizational culture is moderating variables (pure moderator) to the budgetary slack but weaken the relationship between budget participation on budgetary slack, this means that the culture in the environment Organization conducive enough for the people involved (participate) in the preparation the third hospital budget in the research object because of the presence of the organizational culture to reduce and weaken the budgetary slack.

3) Environmental uncertainty

environmental uncertainty condition is one of the factors that often cause the organization to adapt the organization to the environment. Uncertainty can be defined as the individual's perception of the organization. Individuals who are in uncertainty condition due to insufficient 
information to predict the future held their organization. In general, the main source of uncertainty for a society together come from the environment, which consists of customers, suppliers, technologies, competitors and regulators is required (Govindarajan, 1998). Milliken (1978) suggests that in general Individuals will undergo environmental uncertainty if you feel the environment is unpredictable and cannot understand how the components of the environment will change. According to (Duncan, 1972 in Asak, 2014) under conditions of low environmental uncertainty (the environment is relatively stable), individuals can predict the future situation so that measures can be planned to be done with more accuracy. A relatively stable condition can be used by members of the organization to help organizations make accurate planning.

4) Information Asymmetry

Information Asymmetry is an imbalance information which is owned by top managers and the manager down. This happens because of lower managers are directly related to daily operations. According Dunk (1993):"asymmetry information exists only when subordinatesinformation exceeds that of Reviews theirSuperiors." Information Asymmetry occurs when subordinates avoid more information than the boss about an organizational problem. Or in other words the presence of an imbalance of information held subordinate to the information held by employers for their different views and interests. According Dunk (1993) in Widiastuti (2006) information asymmetry is measured by several indicators, such as: 1) the information that subordinates compared to the boss,

2) input-output relationships that exist in internal operations, 3) potential performance, 4) technical work, 5) the ability to assess potential impacts and 6) the achievement of the field of activity. According to Scott (2000: 105) asymmetry of information is divided into two sections, among others: 1) Adverse selection, where the managers as well as people in knowing more about the company information and circumstances that influence the decision to be taken by shareholders. 2) Moral hazard, where the activities carried out by a manager is not entirely known by shareholders and lenders. So that managers can perform actions outside the knowledge of shareholders in violation of the contract and the actual ethics or norms which may not be worth doing. In research Usman (2012) as a moderating variable information asymmetry on budgetary slack but weaken the relationship participation of the budgetary slack implies that the information asymmetry can be minimized with the communication between supervisors and subordinates so that budgetary slack can be decreased.

\section{Hypothesis Development \\ The Effect of Budgetary Participation On Budgetary slack}

The budget participation growing, provides opportunities for Responsibility Center manager to perform budgetaryslack. The occurrence of such events is because the responsibility center manager is given authority to establish the content of their budget and their performance will be assessed based on the budget. Raudhiah (2014) states that a high interaction between budgetary participation, budget emphasis and information asymmetry increase the budgetary slack. However, the achieved performance assessment based on whether or not the company budget targets lead to a budgetaryslack. In addition, the planning and budget preparation companies often lead to budgetaryslack, because budgeting is often dominated by the interests of an individual or group, and less reflective of the needs of stakeholders (Kartiwa,2004). The above statement is supported by the research results Maskun (2008, Young (1985), Siegel and Marconi (1989), Sustainable (2015) stating that the budgetary participation has a positive effect it is different with Supanto (2010), Martjin and Wiersma (2011) which states that the budgetary participation negatively affect the budgetary slack. Based on the above and the inconsistency of the results of previous studies, it can be made a hypothesis is

H1: The budgetary participation has positive effect to Budgetary slack.

Capabilities of Organizational Culture for Moderating Budgetary Participation on Budgetary Slack

Importance of Organizational Culture in the development and processing of individual behavior in the company has been very common to be known. In the era of globalization, companies are expected to have management and operational control are efficient and effective, as well as the main structure. Thus, a conflict of interest between the agent and the principal in the budgeting of the company that may cause slackbudgetscan be anticipated. This is supported by Maskun (2008) that the culture of bureaucratic organization that has undergone a transition to increasingly open communication culture, so as to reduce the occurrence of slack budget.Reysa research results (2011) and Usman (2012) shows that organizational culture is a variable moderating influence on the participatory budget slack budget. However, Falikhatun (2007) and Supanto (2010), shows that the culture of a people-oriented organization (employee oriented) cannot moderate influence on the budgetary participation with budgetary slack. Based on that case, it can be hypothesized.

$\mathrm{H} 2$ : The organizational culture moderating (strengthening) the effect of budgetary participation to budgetary slack.

Capabilities of Environmental Uncertainty for Moderating Budgetary Participation on budgetary 


\section{Slack}

Condition of environmental uncertainty is a sense of inability to accurately predict anything from the entire social and physical factors that directly affect the decision-making behavior of the people in the organization (Milliken, 1987 in Astuti 2007). Environmental uncertainty variable is measured using indicators: lack of information, inability to find out the results, and the inability to determine the possibilities. Environmental uncertainties identified as an important factor for these conditions can complicate planning and control. Planning becomes problematic in situations of uncertain operation for more unpredictable future events.

According to Govindarajan (1986) The main source of uncertainty for an organization comes from the environment, including competitors, customers, suppliers, regulators, and technology required. An individual will have high environmental uncertainty if you feel the environment is unpredictable and cannot understand how the components of the environment will change (Milliken, 1987). According to Duncan (1972) whereas in environmental uncertainty is low (the environment is relatively stable), individuals can predict the state in the future so that the measures that will be done can be planned more accurately In a relatively stable condition can be used by members of the organization in making a accurate decisions that can benefit the organization. Subordinates who actively participate in the preparation of budgets and facing an environment of low uncertainty, will possibly create slack in the budget because he can cope with environmental uncertainty and can predict the future. Instead, the environmental uncertainty, it would be increasingly difficult to predict the future and the more difficult it is creating a budgetary slack. Based on the above description, it can be hypothesized.

H3: The environmental uncertainty moderating (weakening) the effect of budgetary participation to budgetary slack

Capabilities of Asymmetry Information for Moderating Budgetary Participation to budgetary Slack

Te utilities of contingency theory on asymmetry of information is to look at the effects of information in the relationship between budgetary participation on budgetary slack variables, where the information asymmetry here as situational variables that can strengthen or weaken the relationship between the two variables. According to some researchers the information asymmetry that occurs between the principal and the agent who participated in budgeting can lead to budgetary slack this case, because of the asymmetry of information can make the difference relevant information used in making decisions between top-level managers with managers lower levels, this theory is supported by Young (1985), Falikhatun (2007), Djasuli and Fadilah (2011) that the interaction of participatory budgeting and information asymmetry positive and significant impact on budgetary slack. This is in contrast with the results of Fitri (2004), Asak
(2016), and Irfan (2016) that the information asymmetry is not able to moderate the relationship between budget participation on budgetary slack. Based on the foregoing, it can be hypothesized:

H4: The information asymmetry moderating (strengthening) the effect of budgetary participation to budgetary slack.

\section{Methods}

The population in this study were all employees at the District General Hospital Sumbawa Besar. The sampling technique in this study using purposivesampling,ie taking samples in accordance with the criteria established by researchers that are 48 respondents. The variables of this research is measured by using a questionnaire that contains few statements. The statements in this questionnaire is a replication drawn from several previous studies with reference to the theoretical foundation that deals with the study variables. Based on the statements of each of the variables of the study, respondents were asked to provide an assessment or opinion with Likert scale 1-5. Figures 1 shows the ratings or opinions strongly disagree (STS) through 5 which show ratings / opinions strongly agree (SS).

\section{Data Analysis Techniques Validity Test}

Validity test aims to measure the quality of the instruments used and shows the validityor the validity of an instrument as well as how well a concept can be defined by a measure (Hair et al., 2006). Item questionnaire considered valid, if above 0.5 . The validity of the instrument was evaluated based on a convergent and discriminant validity of the indicators are calculated using PLS. Convergent validity assessed based on the correlation (outer loading) between the scores of items or indicators (component score) with a score of constructs.

\section{Reliability Test}

Reliability Test conducted to determine the extent of the measurement device has a measurement accuracy and precision consistent from time to time. Instrument reliability is determined from the value of composite reliability and Cronbach's alpha for each blockade indicator. According Ghozali and Latan (2015), an indicator is said to have good reliability if the value of composite reliability and Cronbach's alpha greater than 0.7 .

\section{Hypothesis Test}

Analysis model used in this study is a component-based SEM (component- based) software smartPLS (Partial Least Square) Ver. 3.2.7. According Ghozali and Latan (2015), PLS is powerful analysis because it is not based on many assumptions. The stages of analysis using PLSSEM according Ghozali and Latan (2015) consists of five stages of the analysis process, ie conceptualization models, determination algorithm analysis method, determination of resampling methods, drawing the path diagram and modelevaluation.Determining whether or not fit a model in this study uses several sizes of average path coefficient (APC), average R-square (ARS) and the average variance inflation factor (AVIF). APC value and ARS should be less than 0.05 and AVIF as an indicator 
must be greater multicolinearity 5 .

\section{Results and Discussion Results of Questionnaire}

Sample of respondents in this study were employees of the Regional General Hospital Sumbawa in charge of finance and participate in the preparation of the budget. The questionnaire was distributed to 48 respondents, while as many as 48 questionnaires were returned, but that can be used and processed in this study amounted to only 45 questionnaires. The rest cannot be used because of incomplete answers and data.

\section{Validity test}

Parameters used to test the validity by looking at the value of the loadingfactor. The results of the validity shown in Table 1 show that almost all the indicators in the constructs in the measurement model have met the requirements, only indicator $\mathrm{X} 4.2, \mathrm{X} 4.3$ and $\mathrm{X} 4.4$ which do not meet the requirements of $0.302,0.064$, and 0.243 so that should be dropped from the model.

After the indicators are dropped, then reanalysis of the model. Based on the results of the analysis, the indicators have a loading factor value $>0.50$. The results of the analysis can be seen in Table 2 below:

Table 1. Cross Loading

\begin{tabular}{|c|c|c|c|c|c|}
\hline Indicators & $\mathrm{X} 1$ & $\mathrm{X} 2$ & $\mathrm{X} 3$ & $\mathrm{X} 4$ & $\mathrm{Y}$ \\
\hline $\mathrm{X} 1.1$ & 0.920 & 0.848 & 0.833 & 0.846 & 0.867 \\
\hline $\mathrm{X} 1.2$ & 0.780 & 0.797 & 0.853 & 0.713 & 0.766 \\
\hline X1.3 & 0.920 & 0.911 & 0.953 & 0.843 & 0.894 \\
\hline X1.4 & 0.941 & 0.894 & 0.878 & 0.845 & 0.899 \\
\hline X1.5 & 0.946 & 0.911 & 0.892 & 0.865 & 0.915 \\
\hline $\mathrm{X} 2.1$ & 0.788 & 0.887 & 0.845 & 0.784 & 0.854 \\
\hline $\mathrm{X} 2.2$ & 0.694 & 0.793 & 0.729 & 0.714 & 0.741 \\
\hline $\mathrm{X} 2.3$ & 0.930 & 0.901 & 0.887 & 0.843 & 0.900 \\
\hline X2.4 & 0.864 & 0.883 & 0.892 & 0.827 & 0.870 \\
\hline $\mathrm{X} 2.5$ & 0.881 & 0.890 & 0.851 & 0.828 & 0.885 \\
\hline X2.6 & 0.814 & 0.837 & 0.791 & 0.781 & 0.850 \\
\hline $\mathrm{X} 2.7$ & 0.911 & 0.911 & 0.937 & 0.852 & 0.903 \\
\hline X3.1 & 0.901 & 0.878 & 0.873 & 0.802 & 0.866 \\
\hline X3.2 & 0.765 & 0.796 & 0.851 & 0.723 & 0.759 \\
\hline X3.3 & 0.754 & 0.718 & 0.746 & 0.668 & 0.711 \\
\hline X3.4 & 0.903 & 0.896 & 0.937 & 0.828 & 0.878 \\
\hline X3.5 & 0.751 & 0.785 & 0.832 & 0.742 & 0.757 \\
\hline X3.6 & 0.687 & 0.733 & 0.795 & 0.658 & 0.703 \\
\hline X3.7 & 0.909 & 0.845 & 0.866 & 0.794 & 0.853 \\
\hline X3.8 & 0.902 & 0.870 & 0.855 & 0.842 & 0.874 \\
\hline X3.9 & 0.768 & 0.812 & 0.840 & 0.730 & 0.797 \\
\hline X3.10 & 0.868 & 0.908 & 0.906 & 0.813 & 0.913 \\
\hline X3.11 & 0.906 & 0.855 & 0.857 & 0.801 & 0.848 \\
\hline X3.12 & 0.841 & 0.852 & 0.877 & 0.770 & 0.826 \\
\hline $\mathrm{X} 4.1$ & 0.935 & 0.904 & 0.883 & 0.873 & 0.905 \\
\hline $\mathrm{X} 4.5$ & 0.822 & 0.840 & 0.794 & 0.801 & 0.857 \\
\hline $\mathrm{X} 4.6$ & 0.855 & 0.874 & 0.872 & 0.827 & 0.889 \\
\hline Y1 & 0.931 & 0.911 & 0.873 & 0.872 & 0.926 \\
\hline $\mathrm{Y} 2$ & 0.808 & 0.870 & 0.877 & 0.785 & 0.839 \\
\hline Y3 & 0.893 & 0.884 & 0.829 & 0.851 & 0.917 \\
\hline Y4 & 0.920 & 0.848 & 0.833 & 0.846 & 0.867 \\
\hline Y5 & 0.780 & 0.797 & 0.853 & 0.713 & 0.766 \\
\hline Y6 & 0.920 & 0.911 & 0.953 & 0.843 & 0.894 \\
\hline
\end{tabular}

Realibility Test
Reliability test is performed to determine the extent to which the measurement tools have accuracy and accuracy of consistent measurements over time. Instrument reliability is determined from the value of composite reliability and cronbach's alpha greater than 0.7 (Ghozali and Latan, 2015).

Tabel 2. Realibility Test

\begin{tabular}{cccl}
\hline Variable & $\begin{array}{c}\text { Composite } \\
\text { Reliability }\end{array}$ & $\begin{array}{c}\text { Cronbach } \\
\text { Alpha }\end{array}$ & Information \\
\hline X1 & 0,957 & 0,942 & Reliable \\
X2 & 0,951 & 0,939 & Reliable \\
X3 & 0,969 & 0,964 & Reliable \\
X4 & 0,879 & 0,855 & Reliable \\
X5 & 0,948 & 0,934 & Reliable \\
\hline
\end{tabular}

Interaction of Hypothesis Results and Moderating variables

Hypothesis test results known from the value of the path coefficients in the process bootstrapping SmartPLS 3 ,evidence of hypothesis seen by comparing $T$ statistics with $\mathrm{T}$ table. The hypothesis is accepted if $T$ statistics bigger than $T$ table 1.68. Below are presented results of hypothesis testing in Table 4 as follows:

Table 4. Tests of Hypotheses Based on Path Coefficient

\begin{tabular}{cccc}
\hline Variable & (STDEV) & T Statistics & Information \\
\hline $\mathrm{X} 1$-> Y & 0.195 & 2.185 & Accepted \\
$\mathrm{X} 1 * \mathrm{X} 2$-> Y & 0.143 & 2.384 & Accepted \\
$\mathrm{X} 1 * \mathrm{X} 3$-> Y & 0.109 & 1,803 & Accepted \\
$\mathrm{X} 1 * \mathrm{X} 4$-> Y & 0.092 & 2.025 & Rejected \\
\hline
\end{tabular}

\section{The Effect of Budgetary Participation to Budgetary} slack

The results of a test of hypothesis 1 (H1) show that budget participation that occurred at the General Hospital (Hospital) Sumbawa Besar, has coefficient Tstatistic (2.185)>T table (1.68), and the value of the original sample (0.426), meaning that budget participation positive and significant impact on budgetary slack. That is, if the budget participation by Sumbawa Besar Hospital improved, it will increase budgetary slack. Conversely, if the participation budget is decreasing, declining budgetary slack. Thus, the hypothesis 1 (H1) can be verified. The results of this study are consistent with the Young (1985), Kartika (2010), Usman (2012), Triana (2012), Raudhiah (2014), Huda (2014) and Lestari (2015), which showed that budget participation affect the budgetary slack.

Capabilities of Organizational Culture for Moderating Budgetary Participation to Budgetary Slack

Hypothesis test results $2(\mathrm{H} 2)$ is a moderating influence organizational culture budgetary participation on budgetary slack in Sumbawa Besar Hospital. Hypothesis test results obtained are coefficient Tstatistic (2.384) $>T$ table (1.68) and the value of the original sample (0.342), 
which means that the interaction of budgetary participation and organizational culture positive and significant impact on budgetary slack. Thus, able to moderate the organizational culture (strengthen) the effect of budget participation on budgetary slack occurring in Sumbawa Besar hospital. The better of organizational culture that occurred in Sumbawa Besar hospital, the greater of tendency to subordinate participation to increase budgetary slack. The results of this study are consistent with research Indriantoro (1999), Reysa (2011), and Indriyani (2014)that organizational culture is a variable that moderates the effect of budget participation on budgetary slack.

Capabilities of Environmental Uncertainty for Moderating Budgetary Participation to Budgetary Slack

Based on the results of hypothesis testing 3 (H3) that environmental uncertainty moderating influence of budget participation on budgetary slack, showing environmental uncertainties in Sumbawa Besar Hospital able to moderate the relationship between budgetary participation and budgetary slack. Coefficient of Tstatistic (1.803)>T table (1.68) and the value of the original sample $(-0.197)$ then, means that the uncertainty of the environment can moderate (weaken) the relationship between budgetary participation and environmental uncertainty. Thus, able to moderate environmental uncertainty (weaken) the relationship between budgetary participation and budgetary slack. It mean the environmental uncertainty that occur in Sumbawa Besar Hospital able to act as variables that moderate the relationship between budgetary participation and budgetary slack. The results of this study are consistent with the results of research conducted by Kartika (2010), Asak (2016), and Fatmawati (2017). The participation rate of the budget would have a positive impact on budgetary slack, in a low environmental uncertainty, the higher the resulting slack budgetary participation will increase as well. Vice versa participation of the budget will have a negative effect on budgetary slack, the environmental uncertainty. A subordinate who has a high participation in the budget and lower face of environmental uncertainty, will be able to create slack in the budget, because it is able to cope with uncertainty and is able to predict the future. In contrast, the high degree of uncertainty, it will be increasingly difficult to predict the future and the more difficult it is creating a budgetary slack.

Capabilities of Asymmetry Information for Moderating Budgetary Participation to budgetary Slack

Based on the test results of hypothesis that information asymmetry is moderating influence of budget participation on budgetary slack, indicating that the hypothesis 4 (H4) was rejected, which results from the interaction between budgetary participation and information asymmetry on budgetary slack is a significant negative effect. So we can conclude that moderate the information asymmetry (weaken) the effect of budget participation on budgetary slackin Sumbawa Besar Hospital. This is in accordance with the contingency theory where the variable information asymmetry which acts as situational variables able to weaken the relationship between the variables of budget participation on budgetary slack. This study is in line with research of Fitri (2004), Usman (2012), Asak (2016), and Irfan (2016) where the information asymmetry is not able to strengthen the relationship between budget participation on budgetary slack, the intention is asymmetry of information could undermine the relationship between budgetary participation budgetary slack.

\section{Conclusion}

Based on the results of the analysis can be concluded that this study proves that the influence of a direct relationship between budget participation on budgetary slack, as shown by their positive influence in a direct relationship between budget participation on budgetary slack occurring in Sumbawa Besar Hospital, In addition the results of the analysis showed that the moderating variable organizational culture able to moderate (strengthening) the relationship between budget participation on budgetary slack, ie the higher the influence of organizational culture that occurred in Sumbawa Besar Hospital, the higher the tendency of participation subordinate to increase the budget gap, then the moderating variable uncertainty environment able to moderate (weaken) the relationship between budgetary participation and budgetary slack, meaning that budget participation occurred in Sumbawa Besar Hospital will have a negative effect on budgetary slack, the environmental uncertainty. a subordinate who has a high participation in the budget and the face of environmental uncertainty is low, will be able to create slack in the budget, because it is able to cope with uncertainty and is able to predict the future, and variable information asymmetry as the moderating variable significant negative effect on the relationship of budget participation with slack budget. That is, the condition of information asymmetry that occurs in Sumbawa Besar Hospital, which occurs between the agent with the principal who participated in the preparation of budgets, can weaken the probability appearance of budgetary slack, It is revealed in the budget, an exchange of local information possessed by the subordinate submitted to boss, but the boss still difficult to understand all the information that goes especially on matters relating to the technical field more understandable by subordinates with know about their job.So it can be concluded that the asymmetry of information is not able to strengthen the relationship of budget participation on budgetary slack in Sumbawa Besar Hospital.

\section{Limitations And Future Research Suggestions}

Limitations of this study will provide guidance and guidelines for future research. First, this study only examines the effect of budget participation on budgetary slack with moderating variables of organizational culture and environmental uncertainty. For further research is needed to develop this research by adding another variable which is the study of budgetary slack. Moreover, it can also test other moderating variables such as the capacity of individuals, group cohesiveness, motivation and so forth are still a few researchers who examine this 
in his research. Second, this study to test limited to one hospital alone. To get a different understanding, it helps if responder group performed at the hospital for more good hospitals owned by the private sector or the government, then the use of mixed method is recommended for the next study, because by using this technique, the results obtained can be explored in and can be viewed from the perspective of diverse and rich than when only using the instrument alone.

\section{References}

Andriyani, Lilik., dan Hidayati, L.A. 2010. Pengaruh Komitmen Organisasi terhadap Hubungan antara Kejelasan Sasaran Anggaran dan Partisipasi Anggaran dengan Senjangan Anggaran, Studi Kasus Pada Pemerintah Kabupaten Magelang. Tesis. Universitas Muhammadiyah Magelang.

Anthony, Robert et al. 1992. Sistem Pengendalian Manajemen, Edisi Keenam. Diterjemahkan oleh Agus Maulana dalam Management Control System. Jakarta: Penerbit Binarupa Aksara.

Ardin. 2017. Pengaruh Anggaran Partisipatif dan Tekanan Anggaran terhadap Senjangan Anggaran dengan Locus Of Control sebagai Variabel Moderasi. Jurnal Katalogis. 5 (3): $22-32$.

Asak, Adnyani P. Rani, dkk. 2016. Kemampuan Asimetri Informasi, Ketidakpastian Lingkungan, Budget Emphasis, Dan Kapasitas Individu Sebagai Variabel Moderasi Terhadap Partisipasi Anggaran Pada Budgetary Slack. EJurnal Ekonomi dan Bisnis Universitas Udayana. 5 (2): 219-228.

Brigham, E., and Daves, P. 2010. Intermediate Finnancial Management Tenth Edition. South Western: Cengage Learning.

Damanik, Ayu Zurlaini. 2011. Pengaruh Budgetary Goal Characteristic dan Keadilan Prosedural Terhadap Kinerja Manajerial. Tesis. Universitas Sumatra Utara.

Darlis, Edfan, 2002. Analisis Pengaruh Komitmen Organisasional dan Ketidakpastian Lingkungan terhadap Hubungan antara Partisipasi Anggaran dengan Senjangan Anggaran. Jurnal Riset Akuntansi Indonesia. 5 (1): $85-100$.

Davis, K., dan Newstrom, J.W. 1985. Human Behavior at Work. Organizational Behavior Seventh Edition. Buku Terjemahan Mc. Graw Hill, inc. Edisi 7 Jilid

\section{Surabaya: Erlangga.}

Djasuli, M., dan Fadilah, N.I. 2011. Efek Interaksi Informasi Asimetri, Budaya Organisasi, Group Cohesiveness dan Motivasi dalam Hubungan Kausal antara Budgeting Participation dan Budgetary slack. Proceeding PESAT (Psikologi, Ekonomi, Sastra, Arsitektur dan
Sipil). 4. ISSN: 1858-2559.

Duncan, R.B. 1972. Characteristics of Organizational Environments and Perceived Environmental Uncertainty. Administrative Science Quarterly. 17:313-327.

Dunk, Alan S. 1993. The Effect of Budget Emphasis and Information Asymmetry on the Relation Between Budgetary Participation and Slack. The Accounting Review. 68 (2): 400-410.

Falikhatun, 2007. Pengaruh Partisipasi Penganggaran Terhadap Budgetary Slack Dengan Variabel Pemoderasi Ketidakpastian Lingkungan Dan Kohesivitas Kelompok. Jurnal Akuntansi Dan Keuangan. 6 (2): 207-221.

Ghozali, Imam, Hengky Latan. 2015. Konsep, Teknik, Aplikasi Menggunakan Smart PLS 3.0 Untuk Penelitian Empiris. Semarang: BP Undip.

Huda, Khoirul, dkk. 2014. Pengaruh Partisipasi Anggaran Terhadap Senjangan Anggaran Dengan Budaya Organisasi Sebagai Variabel Pemoderasi Pada Pt Pos Indonesia (Persero) Singaraja. E-Journal S1 Ak Universitas Pendidikan Ganesha. 2 (1): 23-35.

Indriantoro, Nur dan Bambang, Supomo. 1999, Metodologi Penelitian Bisnis: Untuk Akuntansi dan Manajemen Edisi 1. Yogyakarta: BPFE.

Jensen, M. C and Meckling, W.H. 1976. Theory of the Firm: Managerial Behavior, Agency Costs and Ownership Structure. Journal of Financial Economics. 3 (4): 305-360.

Kahar, H.A Suleman. 2016. Participative Budgeting, Budgetary Slack and Job Satisfaction In The Public Sector. The Journal of Applied Business Research. 32 (6): 1663-1674.

Kartika, Andi. 2010. Pengaruh Komitmen Organisasi Dan Ketidakpastian Lingkungan Dalam Hubungan Antara Partisipasi Anggaran Dengan Senjangan

Anggaran (Studi Empirik Pada Rumah Sakit Swasta Di Kota Semarang). Kajian Akuntansi. 2 (1): 3960 .

Lestari, Ni Komang Tri. 2015. Pengaruh Penganggaran Partisipatif pada Senjangan Anggaran Dimoderasi Ketidakpastian Lingkungan Dan Komitmen Organisasi. E-Jurnal Akuntansi Universitas Udayana. 10 (2): 474-488.

Marfuah. 2014. Pengaruh PArtisipasi Anggaran Terhadap Senjangan Anggaran Dengan Menggunakan Komitmen Organisasi dan, dan Informasi Asimetri Sebagai Variabel Pemoderasi. EKBISI. 3 (2): 200-

218.

Maskun, Ali. 2008. Analisis Faktor Etika, Budaya Birokrasi, Tekanan Sosial, dan Kapasitas Individu terhadap Budgetary slack (Senjangan Anggaran) (Kajian Perilaku Eksekutif dalam Proses Penyusunan Anggaran di Badan Koordinator Wilayah II Jatim). Terakreditasi Dirjen Dikti (2008). 7 (1): 
162-172.

Maya Triana, Yuliusman, Wirmie Eka Putra. 2012. Pengaruh Partisipasi Anggaran, Budget emphasis, dan Locus of Control terhadap Slack Anggaran. (Survei Pada Hotel Berbintang di Kota Jambi). E- jurnal binary ak. 1 (1): 51 56.

Sudarba. 2010. Pengaruh Partisipasi Penganggaran, Komitmen Organisasi dan Ketidakpastian Lingkungan pada Senjangan Anggaran (Studi Kasus Pada Satuan Kerja Perangkat Daerah Se-Kabupaten Tabanan. Tesis. Universitas Udayana Denpasar.

Sugiyono. 2007. Metodologi Penelitian Bisnis. Jakarta: PT. Gramedia.

Sujana, I Ketut, 2010. Pengaruh Partisipasi Penganggaran, Penekanan Anggaran, Komitmen Organisasi, Asimetri Informasi, dan Ketidakpastian Lingkungan terhadap Budgetary Slack. Audit Jurnal Akuntansi dan Bisnis. 5 (2): 325-339.

Sumarno, J. 2005. Pengaruh Komitmen Organisasi dan Gaya Kepemimpinan terhadap Hubungan antara Partisipasi Anggaran dan Kinerja Manajerial. Jurnal Bisnis Strategi.
$14(2)$.

Sundari, Sri, dkk. 2016. The Relation among Budgetary Participation and Budgetary Slack with Organizational Commitment and Leadership Style as Moderating Variable. IOSR Journal of Business and Management. 18 (10): 28-36.

Usman, Ernawaty, dkk. 2012. Analisis Budaya Organisasi Dan Asimetri Informasi Dalam Senjangan Anggaran. Jurnal Akuntansi Multiparadigma (JAMAL). 2 (3): 334-501.

Young, S.M. 1985. Participative Budgeting: The Effects of Risk Aversion and Assymetric Informations on Budgetary Slack. Journal of Accounting Research. 23 (2): 829-842.

Yuhertiana, Indrawati. 2004. Kapasitas Individu dalam Dimensi Budaya, Keberadaan Tekanan Sosial dan Keterkaitannya dengan Budgetary slack. Paper. Fakultas Ekonomi UPN "Veteran" Jawa Timur.

2017. Rencana Bisnis Anggaran (RBA) Rumah Sakit Umum Daerah Sumbawa Tahun 2017. Sumbawa Besar. 